\title{
1570 YILINDA İSTOLNİ BELGRAD SANCAĞI'NDA ERBÂB-I TIMAR
}

\author{
ERBÂB-I TIMAR IN ISTOLNI BELGRADE SANJAK IN 1570
}

\begin{abstract}
Mustafa IŞIK ${ }^{1}$
$\ddot{O} \mathbf{z}$

Endüstri Devrimi'nden önce Orta ve Yeniçağ’da geleneksel ve kuru tarım ekonomisine sahip imparatorlukların asker yetiştirme ve ordu beslemeleri için gereken en önemli unsur toprak ve toprağı işleyen köylü ailesi idi. Nakit ekonomisinin gelişmediği tarım imparatorluklarında devlet arazileri ile onları işleten köylü halkın birleşmesi sonucunda ortaya çıkan tarımsal ürünlerden alınan vergiler aynî alınır ve devlet hizmetindeki kişilere maaş olarak yine aynî verilirdi. Bu sistem Akdeniz Havzası'ndaki tarım imparatorluklarında thema, pronia, ikta ..vb adlarla bilinirken Osmanlı Devleti bu uygulama için Tımar Sistemi ismini kullanmıştır. İncelediğimiz 497 numaralı Tımar İcmal Defteri'ndeki verilerden Macaristan'ın önemli krallık merkezlerinden birisi olan İstolni Belgrad Sancağı'nın Osmanlı hakimiyetinde 1570 yılındaki toplam gelirlerinin has, zeamet ve tımar olarak kimlere ve ne miktarda tahsis edildiği ortaya çıkarılmaya çalışılmıştır. Bu inceleme neticesinde İstolni Belgrad Sancağı'nda Tımar Sistemi'nin tüm unsurlarının var olduğu ve sistemin uygulanarak devlet erkanı ve askerlere rütbelerine göre ilgili sancaktan dirlik/maaş verildiği anlaşılmaktadır.
\end{abstract}

Anahtar Kelimeler : İstolni-Belgrad, Székesfehérvár, Tımar Sistemi, Macaristan

\begin{abstract}
In the medieval and early modern era before the Industrial Revolution, the land and the people who cultivated land were the most important elements for the recruitment and feeding of the army of empires with traditional and dry farming economies. In agricultural empires where the cash system did not develop, taxes on agricultural products produced by the peasants on state lands were collected in kind. The salaries were also given in kind to the people in state service. While this system is known as thema, pronia, ikta, etc. in the agricultural empires in the Mediterranean basin, the Ottoman Empire used the name T1mar - System for this practice. According to the data in Timar İcmal Book no 497; It has been revealed to whom and how much of the total revenues of Istolni Belgrade Sanjak, one of the important kingdom centers of Hungary under Ottoman rule in 1570, was given as has, zeamet and tımar. As a result of this study, it is understood that all elements of the T1mar System was observed in Istolni Belgrade Sanjak and the system was also implemented as the state officials and soldiers were paid dirlik/salary from the related banner according to their rank.
\end{abstract}

Keywords : İstolni-Belgrad, Székesfehérvár, Tımar System, Hungary

\footnotetext{
${ }^{1}$ Dr.öğr.Üyesi, Hatay Mustafa Kemal Üniversitesi, egeli21@hotmail.com, Orcid: 0000-0002-4614-6799

Makale Türü: Araştırma Makalesi - Geliş Tarihi 09-11-2019- Kabul Tarihi:03/04/2020
}

DOI:10.17755/esosder.644672

Atıf için: Elektronik Sosyal Bilimler Dergisi, 2020; 19(75):2138-2152. 


\section{Giriş}

Orta Avrupa'da Tuna, Tisa ve Drava Nehirleri gibi çok büyük su yollarına, bereketli ovalara ve muhkem kalelere sahip olan Macaristan toprakları sahip olduğu stratejik konumundan dolayı hem Osmanlı Devleti hem de Habsburglular için çok önemliydi. 1456 yılında başarısızlıkla sonuçlanan Belgrad Seferi'nden sonra Osmanlı Devleti bir süre Sırbistan ve Macaristan akınlarına ara vermişti. Ancak Kanuni Sultan Süleyman'ın 1521 yılında Macaristan'ın kapısı sayılan Belgrad'ı fethetmesi ardından 1526 yılında Mohaç Savaşı'nda Ortaçağ Macar Krallığı'na son verilmesi neticesinde artık Macar topraklarında Osmanlı hakimiyeti ve idaresi başlayacaktır. Bu çalışmada Macaristan'ın en önemli üç krallık ve taç merkezlerinden birisi olan İstolni Belgrad' in Osmanlı hakimiyeti döneminde nasıl yönetildiği, buranın Osmanlı Devleti'nin hazinesine ne kadar katkı sağladığı ve sancaktaki tımar sistemi dahilinde oluşan yapı ile dirlik sahiplerinin tespit edilmesi hedeflenmiştir. Çalışmada kullanılan metot ise Osmanlı tahrir sistemi kapsamında sancağın 1570 yılında tahrir komisyonu tarafindan tutulan kayıtlarının ve ortaya çıkarılan 497 numaralı Tımar-İcmâl Defteri'ndeki verilerin değerlendirilmesi ve analiz edilmesi olacaktır. Bu bağlamda tımar sisteminin dolayısıyla doğrudan fetih ve hakimiyet usulünün payitahttan oldukça uzak bir sınır bölgesinde nasıl uygulandığı, dirlik sahiplerinin kimlerden oluştuğu, bu kişilerin dini mensubiyeti ve ne kadar gelire sahip oldukları tespit edilmeye çalışılmıştır. Bu çalışma ile Macaristan'daki Osmanlı sancak idaresi ve şehir tarihi alanına katkı sağlanması planlanmaktadir.

\section{1.İstolni Belgrad'ın Kuruluşu ve Kısa Tarihçesi}

Macarca Székesfehérvár, Almanca Stuhlweißenburg ve Latince Alba Regia olarak adlandırılan şehrin ismi Osmanlı Devleti tarafindan İstolni Belgrad veya Belgrad-1 Üngürüs olarak kullanılmıştır(Dávid, 2001: 405). Macaristan'1n batı bölgesinde Balaton Gölü'nün kuzeyinde ve Budin'in $58 \mathrm{~km}$. kuzeybatısında düz bir alan üzerine X.yüzyılda kurulan şehir, Aziz İstvan döneminde (1000-1038) başkent haline gelerek bu özelliğini XVI.yüzyıla kadar sürdürmüştür(Bilge, 2001: 47). Kral Istvan'1n buraya defnedilmesinden sonra Ortaça ğ boyunca Macar krallarının birçoğu burada taç giymiştir. Macaristan'ın diğer krallık merkezleri Budin ${ }^{2}$ ve Estergon ilerleyen süreçte daha fazla önem kazansa da İstolni Belgrad da saygınlığını korumuştur(Dávid, 2001: 405).

İstolni Belgrad'ın kuruluşu hakkında tarihçiler arasında görüş birliği bulunmamaktadır. Şehrin ismine en erken Vesprem Piskoposluk Bölgesi'nin kuruluş belgelerinde rastlanılmaktadır. 1005 y1lına tarihlenen bu belgeden o zamanlarda İstolni Belgrad'ın krallık merkezi olduğu anlaşılmaktadır. Macar kronikleri ise şehrin kuruluşunu şehir merkezine bazilika'nın inşası ile ilişkilendirmektedir. Buna göre; Kral İstvan, Bulgarlar ile yaptığı savaş neticesinde galip geldikten sonra ele geçirdiği ganimet ve hazine ile bu kiliseyi inşa ettirmiştir. Ancak bir diğer iddiaya göre; Kral Geza, 997 y1lında vefat ettiğinde oğlu Istvan I tarafindan son yolcuğu için ilk defa açılan bu kilisede tören düzenlenmiştir. Buradan da bazilikanın Istvan I'den önce inşa edilmiş olduğu anlaşılmaktadır(Fügedi, 1969: 113-115). Bir diğer kaynak da İstolni Belgrad'daki bazilikanın Kral Istvan tarafindan yaptırıldığını belirtmektedir. Buna göre; Kral Istvan idari merkezini değiştirmiş ve ancak Pannonia'daki yeni hac yolunun en kısa güzergâhının Estergon'dan geçmesinden dolayı buraya dokunmayarak kendisine İstolni Belgrad'da yeni bir krallık merkezi kurduktan sonra

\footnotetext{
${ }^{2}$ Obuda, İstolni Belgrad ve Estergon'dan oluşan üçgen, 1000 yılında Macar Krallığının kuruluşundan itibaren devletin başkenti ve merkezi sayılmıştır. Bunlardan Estergon, Macarların Başpiskoposluk merkezi, İstolni Belgrad (Szekesfehervar) kralların taç giydiği ve gömüldüğü merkez iken 13.yüzyıldan itibaren krallar Obuda'da ikamet etmeye başlamışlardır. Detaylı bilgi için Bkz. (Kubinyi, 1991:15).
} 
burada krallığın ibadet ve cenaze işlerinin yapıldığı bir bazilika inşa ettirmiştir(Györfyy, 1971: 8). Yani genel anlamda şehrin kuruluşu ile bazilikanın kuruluşu özdeşleştirilmiştir.

Ortaçağ Macaristanı'nın en önemli şehirlerinden biri olan İstolni Belgrad, bu özelliğini kısmen saygın kiliseleri ve kilise meclislerine kısmen de hareketli ticaretine borçludur. XII.yüzyılda bilhassa önem kazanan şehrin ticareti XVI.yüzyıla kadar bu önemini korumuştur (Fügedi, 1969: 103).

Osmanlı Devleti, İstanbul'un fethinden sonra cihan-şümul bir siyaset takip ederek dünya hakimiyetini hedeflediğinden yönünü batıya çevirerek Avrupa'da büyük bir güç olan Habsburglular üzerine yürümüştür. Bu bağlamda Kanuni Sultan Süleyman Orta Avrupa'ya ulaşabilmek için kilit konumda yer alan Belgrad'1 1521 yılında ve Budin'i ise 1541 yılında ele geçirmiştir(İnalcık, 2009: 149-159).

1541 yılında Budin'de Osmanlı hakimiyetinin kurulması ve idare merkezinin Budin'in Beylerbeyliği olarak belirlenmesinden sonra Macaristan'daki Osmanlı hakimiyetinin güvenliğini tesis etmek için Osmanlı Devleti, Macaristan'da stratejik açıdan önemli noktalar üzerine sefere çıkmıştır(Kopcăn, 1973: 619). İstolni Belgrad'ın Osmanlı hakimiyetine girişi Kanuni Sultan Süleyman'ın 1543'teki Estergon Seferi'nin bir sonucudur. Estergon üzerine planlanan bu seferin en önemli nedeni Osmanlı ordusunun İstanbul'a dönüşünden sonra Ferdinand'ın Budin ve Peşte'yi muhasara etmesidir. Bunun üzerine Sultan Süleyman 23 Nisan 1543 tarihinde bizzat başta kendisi bulunarak Macaristan üzerine tekrar sefere çıkmıştır. Bu esnada Budin'deki Türklerin sayısı 8.000 civarında iken Ferdinand'ın kuvvetleri 80.000 civarındaydı. Padişahın ordusuyla geldiğini duyan Ferdinand geri çekilmiş, Osmanlı ordusu ise Ferdinand'1n elinde bulunan Estergon ve İstolni Belgrad'1 alarak İstanbul'a geri dönmüştür(Uzunçarş1l1, 1998: 338-339, Yücel, 1991: 75-76, Gökbilgin, 1997: 128-129, İpçioğlu, 1990:158, Schaendlinger, 1984: 189). Fetihten sonra Sultan Süleyman, İstolni Belgrad'da Macar krallarının defnedilmiş ${ }^{3}$ olmasının önemine saygı göstererek küçük bir kilisenin camiye çevrilmesini emretmiş ve büyük katedrale dokunmamıştır(Turan, 2005: 48).

İstolni Belgrad'ın 4 Eylül 1543 tarihinde Osmanlı hakimiyetine girmesinden sonra ilk sancakbeyliğine 600.000 akçe has ile Budin Beylerbeyi Yahya Paşa'nın kardeşi İnebahtı Beyi Yahyapaşazade Ahmed Bey tayin olunmuş ve emrine 4000 kişilik bir askeri garnizon tahsis edilmiştir(Peçevi, 1981:187). İstolni Belgrad Kadılığına ise Beğlizade Recep Efendi atanmıştır(Evliya Çelebi, 2011: 3725). Osmanlı Macaristanı'nda yer alan şehirlerin Osmanlı hakimiyeti dönemindeki gelişimleri ${ }^{4}$ için İnalcık, Macaristan'da Osmanlı ve Türk kültürünün fetihlerden sonra özellikle Budin, Peşte, Szeged ve İstolni Belgrad gibi büyük yönetim merkezlerinde geliştiğini ifade etmektedir. Ekonomik gelişmelerin ise özellikle Tuna Nehri üzerinde iskeleye sahip olan Estergon, Vac ve Kuvin gibi bölgelerde geliştiğini, İstolni Belgrad ve Solnok'un gelişimlerinin stratejik koşullardan ileri geldiğini savunmaktadır(İnalc1k ve Quataert, 2000: 366).

XVII.yüzyılda şehri ziyaret eden Evliya Çelebi, 2000'i cebeli toplam 3000 asker tarafindan korunan İstolni Belgrad Kalesi'nin etrafinın 6000 adım olduğunu, çevresinin bataklıklarla çevrili ve hendeksiz olduğunu, 13 zeameti ve 355 adet tımarı olduğunu söylemektedir. Evliya Çelebi'nin ifadelerinden İstolni Belgrad'ın 9 büyük tabyası ve her

\footnotetext{
${ }^{3}$ Mohaç Savaşı'nda Kanuni Sultan Süleyman'a yenilerek savaş meydanında hayatını kaybeden Macar Kralı II.Lajos, 9 Kasım 1526 tarihinde İstolni Belgrad'da defnedilmiştir. Bkz. (Kaldy-Nagy, 1974-a:177).

4 Macaristan'da Osmanlı Hakimiyeti döneminde Beylerbeyileri tarafından önemli sosyal, kültürel, eğitimsel ve dini yapılar inşa ettirilmiştir. Örneğin Sokullu Mustafa Paşa'nın beylerbeyliği döneminde Budin'de 1 cami ve 2 küçük mescit ile 12 odalı bir medrese, Peşte'de 1 cami ve 1 medrese, İstolni Belgrad'da 1 cami ve 1 mescit, Ösek’te 1 cami, Nemci, Fülek ve Földvar'da da birer cami inşa ettirmiştir. Bkz. (Kaldy-Nagy, 1972: 446).
} 
tabyada 40-50 adet balyemez toplarının bulunduğunu, varoşunda ise 4 cami, 4 medrese ve 11 tekkenin var olduğunu anlıyoruz(Evliya Çelebi, 2011: 3729-3735).

İstolni Belgrad, 1543 yılından 1602 yılına kadar 59 y1l ve 1603 yılından 1688 yılına kadar 85 yıl olmak üzere toplamda 144 yıl boyunca Osmanlı hakimiyetinde kalmıştır(Dávid, 2001: 405).

\section{Teorik Olarak Tımar Sistemi ve Uygulanması}

Türkçe'de dirlik sözcügünün eş anlamlısı olarak kullanılan tımar kelimesinin sözlükteki karşılığı bakım veya ilgi olarak ifade edilmektedir. Osmanlı tarihi terminolojisinde ise tımar Osmanlı Devleti'nde askeri veya idari bir hiyerarşiyi ekonomik olarak desteklemek ve finanse etmek için tevarüs yoluyla devredilemeyen tahsisat anlamına gelmektedir(İnalcık, 2012: 168). Halil İnalcık tımar kelimesini bu şekilde açıklarken Ömer Lütfi Barkan tımarı "Timar, Osmanlı Imparatorluğunda geçimlerini veya hizmetlerine âit masrafları karşılamak üzere bir kısım asker ve me'murlara, muayyen bölgelerden kendi nam ve hesaplarına tahsîli selâhiyeti ile birlikte tahsis edilmiş olan vergi kaynaklarina ve bu arada bilhassa defter yazllarındaki senelik geliri 20.000 akçeye kadar olan askerî dirliklere verilen isimdir" (Barkan, 1977: 286) şeklinde açıklamaktadır. Mustafa Akdağ da tımarı devletin kendi hizmetindeki kişilere görevleri karşılığında nakit para vermek yerine bazı bölgelerin aynî gelirlerini kendi nam ve hesaplarına toplamaları için verilen yetki olarak ifade etmektedir(Akdağ, 1945: 419). Bu açıdan bakıldığında her üç açıklamadan da para ekonomisinin yeterince gelişmediği Orta ve Yeniçağ' da ekonomik şartlar ve tarihi zaruretler nedeniyle devletlerin aynî ekonomi sistemini benimsemelerinden dolayı vergilerin aynî olarak alındığ Lütfi Barkan, tımar sistemini ekonomik şartlar ve tarihi zaruretlerin neticesinde kendiliğinden ortaya çıkan doğal bir sistem olduğunu ve dolayısıyla herhangi bir ırka veya devlete mal edilemeyeceğini ifade etmektedir(Barkan, 1977: 293). Türk imparatorluklarında tımar sistemi esasında Türklerin XI.yüzyılda İslam dünyasında egemen güç haline geldikten sonra kendi askeri gelenek ve teşkilatlarıyla yerli müesseseleri sentez yapmaları sonucunda ortaya çıkmıştır. Osmanlılar da bu rejimi mevcut durumdaki şartlara göre düzenleyerek geliştirerek devletlerini ayakta tutabilmişlerdir(İnalcık, 1964: 758). Osmanlı Devleti'nde çok önemli askerî, idârî, mâlî ve içtimâi bir müessese olan tımar sistemi'nin menşei ve Avrupa'daki uygulamaları arasındaki benzerlikleri ve farklılıkları hakkında en kapsamlı çalışmalardan birisi Yücel Öztürk tarafindan yapılmıştır. Öztürk, tımar ile thema terimlerinin ortaya çıkışını ve uygulamalarını birbiriyle mukayese ettiği çalışmasında; Bizans İmparatorluğu'nda VII.yüzy1ldan itibaren kullanılan thema, themata, tagma, tagmata tabirlerinin Asya menşeli tümen ve bunun Moğolca'daki karşıllğı tamma ile bağlantılı olduğunu ve bu sistemin Bizans'a Sasaniler, Avarlar ve Peçenekler vasıtasıyla sirayet ettiğini savunmaktadır. Öztürk ayrıca Bizans proniası ile Osmanlı tımarının aynı olduğunu ikisi arasında en önemli farkın merkezi otoritenin uygulanması açısından ortaya çıktığını ancak her iki sistemin de zamanla değişim göstererek thema sisteminin pronia'ya buna karşın tımar sisteminin de mâlikâneye dönüştüğünü ifade etmektedir(Öztürk, 2013: 161-204).

Sistemin etimolojisi ve menşeinden sonra kısaca işleyişinden ve unsurlarından bahsetmek gerekmektedir. Tımar Sistemi bünyesinde hizmetleri karşılığında dirlik verilen kişiler sahib-i arz olarak adlandırılsalar da bunlar toprağın gerçek mülkiyetine sahip değillerdi. Hizmetleri ve sadakatleri devam ettiği sürece dirliklerinin tasarruf haklarına ve dirlikleri dahilindeki reaya üzerinde bir takım feodaliteye benzer haklara sahiptiler. Bu amaçla dirlik sahibi toprağını satamaz, vakfedemez ve miras bırakamazdı. Devlet bu uygulama ile dirlik sahiplerinin miras yoluyla büyük aile mülkleri oluşturmak suretiyle tehdit unsuru haline gelmelerine karşı önlem almış olmaktaydı. Bu uygulama esasında Avrupa'daki feodaliteye oldukça benzer bir uygulama olup üretimin devamı ve verimin korunması için bazı zaruri 
uygulamaları gerektirmekteydi(Barkan, 1977: 295-306, Fekete, 1961: 30-31, Acun, 2002: 901).

Osmanlı Devleti'nde dirlikler tımar sistemi dahilinde sınıfların görev ve özelliklerine göre "has", "zeamet" ve "tımar" olmak üzere üç ana kategoride toplanmıştır. Hiyerarşinin en üst katmanında bulunan ve 100.000 akçenin üzerindeki gelirlerden oluşan haslar da kendi içerisinde havass-1 hümayun ve havass-1 vüzera olmak üzere ikiye ayrılırdı. Havass-1 hümayun olarak kaydedilen gelirler prensipte padişaha ait gelirler olarak görülse de esasen bu gelirler hazine için tahsis edilmiş olup en zengin ve güvenilir gelirler bu kategoriye dahil edilmiştir. Havass-1 vüzera olarak kaydedilen gelirler ise beylerbeyi, paşa, vezir...vb. üst düzey devlet memurları için verilen dirliklerdir. Hiyerarşinin ikinci kademesinde bulunan zeametler ise 20.000 akçe ile 100.000 akçe arasındaki gelirleri kapsamakta ve yüksek mertebeli devlet görevlilerine tahsis edilmiştir. Hiyerarşinin en alt basamağında bulunan tımarlar ise 0 ila 20.000 akçe arası gelirleri kapsamakta ve genelde sipahilere ve savaşçılara tezkereli veya tezkeresiz olarak verilirdi. Bu tımarlar ilk verildiği zaman "kılıç" tımarı şeklinde adlandırılmakta ve çekirdek kadro ya da başlangıç tımarı olarak verilmekteydi. Zaman içerisinde sipahi savaşlarda gösterdiği başarılar sonucunda terakki almak suretiyle tımarını 20.000 akçeye kadar yükseltebilmekteydi(İnalcık, 2012: 169-170). Bir tımar sahibinin aldığı terakkiler ile zamanla 20.000 akçeye ulaştığ zaman tımarı zeamete çevrilebilmekte kendisi de zaim taifesine geçebilmekteydi. Ancak bu durum, savaşta istisnai ve olağanüstü bir başarı elde edebilen yani 15 esir veya 15 kelle getiren sipahiler için geçerliydi. Ayrıca, zeametler bey oğullarına ve yüksek rütbeli devlet görevlilerine ayrıldığından genel anlamda tımarın zeamete dönüştürülmesi sınırlıydı(Özünlü, 2010: 240).

Tımar sistemi dahilinde dirlikler dağıtılırken sipahinin mutlaka Müslüman olma şartı olmadığından gayrimüslimlere de hizmetleri karşılığında dirlik verilebilirdi. Osmanlılar, hem kırsalda hem de şehirlerdeki Macar muhtarlarına kendi adamları gözüyle bakarlar ve hizmetleri karşılığında onları bazı vergilerden muaf tutarlar hatta maaş bile öderlerdi. Bu maaşı da nakit olarak değil ayni olarak yani tımar gibi tahsis ederlerdi. Mesela 1547'de Peter Nagy isimli Budin Muhtarı, sipahi sıfatıyla tımar almış ve de Canbek Dalyanı'nı mukataa usulü kiralamıştı(Fekete, 1949: 696).

\section{1570 Yılında İstolni Belgrad Sancağı'nda Dirlik Sahipleri}

Makalenin konusunu ve temelini oluşturan, Cumhurbaşkanlığı Devlet Arşivleri Başkanlı̆̆ 1 Osmanlı Arşivi'nde bulunan T.T. 0497 numaralı ve 1570 tarihli tımar icmal defter, 45,5 x 16,5 ebadında ciltli ve ebrusuz olarak sayfa usulüne göre 102 sayfa olarak numaralandırılmıştır. Söz konusu defter, Budin ümerasından Peçuy Sancakbeyi Mehmed Emin ve Ahkâm-1 Mâliye kâtiplerinden İbrahim'den oluşan tahrir heyeti tarafından hazırlandıktan sonra H. 15 Ramazan 977 (M. 21 Şubat 1570) tarihinde padişaha takdim edilmiştir. İstanbul'da gerekli kontrollerden geçirildikten sonra şer-i şerife ve kanuna uygun olduğu anlaşılan 497 numaralı tımar icmal defter, H. Evâhir-i Cemaziy'el Ahir 978 (M. Kasım 1570) tarihinde hazine-i padişahiye teslim edilerek yürürlüğe girmiştir(B.O.A. T.T.0497: 6-7).

İncelediğimiz defterdeki verilerden yola çıkarak Avusturya serhaddinde bulunan önemli sancaklardan birisi olan İstolni Belgrad'ın tahrir edilen gelirlerinin 1570 yılında tımar sistemi dahilinde ne şekilde dağıtıldığını aşağıdaki tablolar vasıtasıyla ortaya koymaya gayret edeceğiz. Buna göre; 1570 yılında İstolni Belgrad Sancağı'nda kayda alınan gelirlerin Klasik Osmanlı Tımar Sistemi dahilinde has, zeamet ve tımar olmak üzere üç farklı dirlik şeklinde dağıtıldığı anlaşılmaktadır. 1570 yılında İstolni Belgrad Sancağı'ndaki havass-1 hümâyun ve havass-1 vüzerâ aşağıda Tablo 1 ve Tablo 2'de gösterilmiştir. 
Tablo 1: 1570 Yılında İstolni Belgrad Sancağı'ndaki Padişah Hasları

\begin{tabular}{|l|c|}
\hline Nefs-i Varoş-ı İstolni Belgrad & Miktarı \\
\hline Mahsûl-ü gümrük ve hamr ve dönüm-ü zemin & 20.000 \\
\hline Mahsûl-ü bâc-1 bazâr ve resm-i sergi ve bâc-1 üserâ ve esb ve gâv fi sene & 15.000 \\
\hline Mahsûl-ü beyt-ül mâl ve mâl-1 gâib ve mâl-1 mefkûd ve yavâ ve kaçûn & 10.000 \\
\hline Mahsûl-ü şemhâne ve ihtisâb ve ihzariye fi sene & 15.000 \\
\hline Mahsûl-ü icâre-i dekâkin fi sene & 10.000 \\
\hline Mahsûl-ü buzhâne ve serhâne fi sene & 4000 \\
\hline Mahsûl-ü bâc-1 kanâre-i gâv ve ganem fi sene & 5000 \\
\hline Mahsûl-ü ? & 10.000 \\
\hline Mahsûl-ü varoş-1 --?an öşr-i gallat ve şire ve saz & 50.000 \\
\hline An mahsul-ü an karye-i --? ve öşr-i galat ve şire ve saz fi sene & 40.000 \\
\hline Mahsûl-i an karye-i --? hanâzir ve öşr-i galat ve şire ve saz resm-i filori & 53.300 \\
\hline Mahsûl-i an karye-i Kis? An öşr-i galat ve şire ve saz resm-i filori & 41.450 \\
\hline Mahsûl-i an karye-i --? öşr-i galat ve şire ve saz resm-i filori & 37.050 \\
\hline Mahsûl-i an karye-i --? öşr-i galat ve şire ve saz resm-i filori & 53.400 \\
\hline Mahsûl-i an karye-i Nakus ?an öşr-i galat ve şire ve saz & 17.500 \\
\hline Mahsûl-i an karye-i Ujfalu tâbi-i İstolni Belgrad An öşr-i galat ve şire & 11.000 \\
\hline Mahsûl-i an karye-i Hafovar? Maa karye-i --? tâbi-i m. An öşr-i galat ve şire & 6300 \\
\hline An mahsul-i --? beher saz fi sene & 1000 \\
\hline An mahsul-i --? hanazır der karye-i Hafovar? tabi-i Belgrad & 2000 \\
\hline Yekûn & $\mathbf{4 0 2 . 0 0 0}$ \\
\hline
\end{tabular}

Tablo 1'deki verilere göre; 1570 y1lında İstolni Belgrad Sancağı'nın gelirlerinin 402.000 akçesi havass-1 hümâyûn (padişah hassi) olarak kaydedilmiştir. Padişah hassı olarak kaydedilen 402.000 akçelik gelir grubuna bakacak olursak; bu gelirlerin içerisinde gümrük vergileri, zemin vergileri, pazar ve sergi vergileri, esir ticaretinden elde edilen gelirler, mumhane, ihtisab ve ihzariye gelirleri, dükkan kiraları, küçükbaş ve büyükbaş hayvan kesimhanelerinden alınan vergiler gibi şehre ait olan ve en garanti vergi kaynaklarının padişah hassı olarak kaydedildiği anlaşılmaktadır. Şehirsel gelirlerden başka yüksek miktarda öşr-i galat, şire ve saz başlı̆̆ı altında İstolni Belgrad'ın kırsalındaki bazı köy ve varoşların gelirlerinin de havass-1 hümâyûna dahil edildiği görülmektedir. Bu açıdan incelendiğinde diğer eyalet ve sancaklardaki klasik uygulamaların İstolni Belgrad Sancağı'nda da devam ettirildiğini ifade edebiliriz.

Havass-1 hümâyundan sonra İstolni Belgrad Sancak Beyi Mehmed Bey ile Vidin Sancak Beyi Hamza Bey’e verilen gelirler havass-1 vüzerâ olarak aşağıda gösterilmiștir. 
Tablo 2: 1570 Yılında İstolni Belgrad Sancakbeyi Mehmed Bey’in Hasları

\begin{tabular}{|l|c|}
\hline Nâhiye-i İstolni Belgrad der livâ-i m. & Miktarı \\
\hline Varoş-1 İstolni Belgrad & 36.000 \\
\hline Karye-i Sağ? Tâbi-i m. & 5500 \\
\hline Karye-i Sombor? Maa --? & 5000 \\
\hline Karye-i Örös? Tab-i m. & 6000 \\
\hline Karye-i Sönöke? maa mezra-i düven? ve vraç? tâbi-i m. & 12.436 \\
\hline------------ ? & 2000 \\
\hline Nâhiye-i Sirem & 45.452 \\
\hline Nahiye-i Palota? der liva-i İstolni Belgrad & 30.159 \\
\hline Nahiye-i Yehun? der liva-i m. & 27.231 \\
\hline Nahiye-i Varadin? der liva-i m. & 10.528 \\
\hline Nahiye-i Tata der liva-i İstolni Belgrad & 39.164 \\
\hline Nahiye-i Sisek? tabi-i liva-i m. & 37.202 \\
\hline Nahiye-i Tata der liva-i m. (ber vech-i tahmin) & 13.599 \\
\hline Cem'an gayr-i ez Havas-ı Kopan ve Şimontorina & $\mathbf{2 7 0 . 2 7 1}$ \\
\hline
\end{tabular}

Tablo 2'deki verileri analiz edecek olursak; İstolni Belgrad Sancak Beyi Mehmed Bey'e 1570 yılında Kopan ve Şimontorina sancaklarındaki haslarından başka İstolni Belgrad Sancağ1 gelirlerinden toplam 270.271 akçe tahsis edildiği anlaşılmaktadır. Mehmed Beye tevzi edilen hasların çoğunluğu İstolni Belgrad, Sirem, Varadin, Tata gibi nahiye ve varoşlardan sağlanmıştır. Burada dikkat çeken bir diğer önemli husus ise Tata Nahiyesi'nden 13.599 akçelik bir gelirin ber vech-i tahmin olarak tahsis edilmiş olmasıdır. Tımar sistemi içerisinde dirlik dağıtım modellerinden bir tanesi olan ber vech-i tahmin yöntemi esasen herhangi bir sebepten dolayı gelirin tam olarak hesaplanmadığ 1 , tahminden ibaret olduğu modeldir. Özellikle sınır bölgelerinde tahrir komisyonlarının gitmeye cesaret edemediği yerlerin gelirlerinin tahminen yazılması esasına dayanan bu yöntem çok sağlıklı olmayabilirdi(Kaldy-Nagy, 1996: 51, Kaldy-Nagy, 1974-b: 502).

Yine 497 numaralı tımar icmal defterde kayıtlı olan ancak nereden ve hangi gelirlerden oluştuğu ayrıntısıyla tasrih edilmeyen sadece toplam 24.247 akçe tutarında bir meblağın Vidin Sancakbeyi Hamza Bey'e has olarak tahsis edildiğini de belirtmemiz gerekmektedir. Tablo 2'deki İstolni Belgrad Sancak Beyi Mehmed Beyin 270.271 akçelik hass1 ile burada zikrettiğimiz ancak müstakil bir tablo yapmadığımız Vidin Sancakbeyi Hamza Bey’in 24.247 akçelik has gelirlerini topladığımızda 1570 yılında İstolni Belgrad Sancağı'ndaki Havass-1 Vüzerâ meblağının 294.518 akçeye ulaştığını görmekteyiz.

Havass-1 Hümâyûn ve Havass-1 vüzerâdan sonra zeamet olarak tahsis edilen sancak gelirlerinin sahipleri ve miktarları aşağıda Tablo 3 'te gösterilmiştir. 
Tablo 3: 1570 Yılında İstolni Belgrad Sancağı'ndaki Zeamet Sahipleri ve Miktarları

\begin{tabular}{|l|c|}
\hline Zeamet Sahibin İsmi & Miktarı \\
\hline Zeamet-i Mustafa Miralay-1 Livâ-i M. & 21.350 \\
\hline Zeamet-i Mustafa & 21.500 \\
\hline Zeamet-i Mehmed Kethüda & 21.200 \\
\hline Zeamet-i Divane Pervane? & 20.000 \\
\hline Toplam & $\mathbf{8 4 . 0 5 0}$ \\
\hline
\end{tabular}

Tablo 3'e göre 1570 yılında İstolni Belgrad Sancağı'nda dört adet zeametin bulunduğu görülmektedir. Dört adet zeamet içerisindeki en yüksek meblağ 21.350 akçe ile mezkur sancağın Miralayı Zâim Mustafa Beğ’e tahsis edilmiştir. En düşük meblağa sahip zeamet ise Divane Pervane isimli zâime tahsis edilmiştir. Tahrir yapıldığı yılda İstolni Belgrad Sancağı'ndaki zeamet olarak tahsis ve kaydedilen toplam gelir miktarı 84.050 akçedir. Burada tahsis edilen zeametlerin miktarlarının çok yüksek meblağlı olmadıkları, birbirlerine yakın oldukları hatta tımardan çok az farkla yüksek olarak zeamet kategorisine dahil edildikleri anlaşılmaktadır. Burada kaydedilen zâimler, muhtemelen daha önce tımar sahibi olup da terakki almak suretiyle gelirlerini 20.000 akçe ve üzerine çıkarmayı başarabilmiş olan sipahiler olmalıdır. Tüm bu verilerden de İstolni Belgrad Sancağı dahilindeki zeametlerin esasen en düşük meblağa sahip olduklarını ve dört adet zeametin toplamının dahi has seviyesine ulaşamadığını ifade etmeliyiz.

1570 yılında İstolni Belgrad Sancağı'nda tımar sistemi içerisinde has ve zeametlerden sonra en alt kademedeki dirlikler olan sipahi tımarları aşa ğıda Tablo 4 'te verilmiştir.

Tablo 4: 1570 Yılında İstolni Belgrad Sancağı’ndaki Erbab-ı Tımar

\begin{tabular}{|l|c|}
\hline Tımar Sahibinin İsmi & Miktarı \\
\hline Tımar-1 Tur Ali bin Hasan & 18.500 \\
\hline Tımar-1 Ömer Ağa & 17.500 \\
\hline Tımar-1 İskender & 16.000 \\
\hline Tımar-1 Hüseyin Eflak? & 15.400 \\
\hline Tımar-1 Hamza bin Abdullah & 14.500 \\
\hline Tımar-1 Davud bin Veli & 13.000 \\
\hline Tımar-1 Cafer Ağa --? Derviş Beğ & 13.000 \\
\hline Tımar-1 Divane Ali & 12.800 \\
\hline Tımar-1 Mümin? Serasker-i Sipahiyân-1 Livâ-i İ.Belgrad & 11.500 \\
\hline Tımar-1 Mehmed bin Mahmud & 10.500 \\
\hline Tımar-1 Hamza bin Abdullah 7333 akçe + (ber vech-i tekmil) & 10.500 \\
\hline Tımar-1 Mehmed bin Hayreddin & 10.200 \\
\hline Tımar-1 Divâne Şahin & 10.000 \\
\hline Tımar-1 Süleyman bin Davud an Yeniçeriyân-I Dergâh-1 Âli & 10.000 \\
\hline
\end{tabular}




\begin{tabular}{|c|c|}
\hline T1mar-1 Hüseyin & 10.000 \\
\hline Timar-1 --? & 9900 \\
\hline Timar-1 Mustafa & 9333 \\
\hline Timar-1 Nasuh an çavuşân-1 Budun & 8000 \\
\hline Timar-1 Ahmed & 9000 \\
\hline Timar-1 Mehmed bin Halil & 9000 \\
\hline Timar-1 --? & 9000 \\
\hline Timar-1 Hüseyin bin Mehmed 7500 akçe + (ber vech-i tekmil) & 9000 \\
\hline T1mar-1 İbrahim & 8999 \\
\hline T1mar-1 İskender bin Mehmed & 8900 \\
\hline Timar-1 Sefer Ağa & 8900 \\
\hline Tımar-1 Veli bin Ahmed 7000 akçe + (ber vech-i tekmil) & 8789 \\
\hline T1mar-1 --? bin Ali & 8500 \\
\hline Timar-1 Mustafa bin Şaban & 8500 \\
\hline T1mar-1 Mehmed bin Mustafa & 8800 \\
\hline Timar-1 Bâli bin İsmail & 8500 \\
\hline Timar-1 Süleyman & 8500 \\
\hline Tımar-1 Hacı bin --? an çavuşan-1 defter-i budun & 8500 \\
\hline Tımar-1 Durmuş & 8500 \\
\hline Tımar-1 İbrahim A ğa & 8400 \\
\hline Timar-1 İnehan bin Mehmed & 8166 \\
\hline Timar-1 Cafer bin Abdullah & 8000 \\
\hline Timar-1 Divane Ferhad & 8000 \\
\hline Timar-1 Ali & 8000 \\
\hline Timar-1 Recep bin Abdullah & 8000 \\
\hline Timar-1 Mehmed bin Alagöz & 8000 \\
\hline Tımar-1 Ali bin Şaban & 8000 \\
\hline Timar-1 Temür bin Süleyman & 8000 \\
\hline Timar-1 Abdi bin Mustafa (ber vech-i tekmil) & 8000 \\
\hline Timar-1 Divane Murad (ber vech-i tekmil) & 8000 \\
\hline Timar-1 Ferhad & 8000 \\
\hline T1mar-1 Hüseyin 6666 akçe + (ber vech-i tekmil) & 8000 \\
\hline T1mar-1 Yusuf bin Abdullah (ber vech-i tekmil) & 8000 \\
\hline Timar-1 Mustafa bin --? & 8000 \\
\hline
\end{tabular}




\begin{tabular}{|c|c|}
\hline Timar-1 Ferhad --? Ahmed Beğ & 8000 \\
\hline Tımar-1 Hüseyin bin Üveys & 8000 \\
\hline Timar-1 Mustafa bin Abdullah & 8000 \\
\hline Timar-1 Recep an çavuşan-1 defter-i budun & 8000 \\
\hline T1mar-1 Hüseyin Bin Sinan & 7500 \\
\hline Timar-1 Hasan bin Veli & 7500 \\
\hline Timar-1 Pervane & 7500 \\
\hline Timar-1 İsa bin Davud & 7500 \\
\hline Timar-1 --? bin Oruç & 7500 \\
\hline Tımar-1 --? Derviş Beğ & 7500 \\
\hline Timar-1 Ali bin Hasan & 8000 \\
\hline Timar-1 Recep Bin Veli & 7499 \\
\hline Timar-1 İnehan bin Ali & 7337 \\
\hline Tımar-1 Veli bin İskender & 7300 \\
\hline Tımar-1 Oruç Bin Mehmed & 7300 \\
\hline Timar-1 Cafer bin Abdullah & 7248 \\
\hline Timar-1 Yusuf & 7000 \\
\hline Timar-1 Turhan & 7000 \\
\hline Timar-1 Pir Ali & 7000 \\
\hline Timar-1 Ali bin Abdullah & 7000 \\
\hline Timar-1 Mehmed bin Ahmed & 7000 \\
\hline Timar-1 --? bin Abdullah & 7000 \\
\hline Tımar-1 Hüseyin bin Abdullah & 7000 \\
\hline Timar-1 Abdurrahman (ber vech-i tekmil) & 7000 \\
\hline T1mar-1 Ferhad bin Temürhan & 7000 \\
\hline Timar-1 Ramazan bin Veli (ber vech-i tekmil) & 7000 \\
\hline Timar-1 Ridvan bin Abdullah & 7000 \\
\hline Timar-1 İbrahim bin Abdullah & 7000 \\
\hline Timar-1 Kurt Ali bin Mehmed & 6900 \\
\hline T1mar-1 Ahmed bin Hacı Mehmed & 6900 \\
\hline Tımar-1 Şehsuvar bin Abdullah & 6800 \\
\hline Timar-1 Hasan bin Orhan Çavuş & 6750 \\
\hline Timar-1 Arslan bin İnehan & 6666 \\
\hline Timar-1 Kurt Mehmed & 6666 \\
\hline
\end{tabular}




\begin{tabular}{|c|c|}
\hline Timar-1 Şaban & 6666 \\
\hline Timar-1 Hasan bin Murad & 6666 \\
\hline Timar-1 Yunus & 6666 \\
\hline Timar-1 Bâli Divâne & 6666 \\
\hline Timar-1 Hasan bin Veli & 6500 \\
\hline Timar-1 Mehmed & 6500 \\
\hline Tımar-1 Hasan bin Hüseyin & 6500 \\
\hline Timar-1 Arnavud Mehmed & 6500 \\
\hline T1mar-1 Ferhad? & 6500 \\
\hline Tımar-1 Osman birader-i Mehmed çavuş an yeniçeriyan-1 Budun & 6500 \\
\hline Timar-1 Ali bin Abdullah & 6500 \\
\hline Timar-1 --? bin Mustafa & 6500 \\
\hline Timar-1 Mustafa & 6400 \\
\hline Timar-1 Hacı Hasan & 6300 \\
\hline Timar-1 Ali & 6300 \\
\hline Timar-1 Şaban & 6000 \\
\hline Timar-1 İbrahim bin Murad & 6000 \\
\hline T1mar-1 Hüseyin bin Abdullah & 6000 \\
\hline Tımar-1 Divane Şaban & 6000 \\
\hline Timar-1 Cafer bin Bedri & 6000 \\
\hline Tımar-1 Macar Ali bin Abdullah & 6000 \\
\hline Timar-1 Ahmed & 6000 \\
\hline Tımar-1 Hamza İlyas (ber vech-i tekmil) & 6000 \\
\hline Timar-1 Pervane & 6000 \\
\hline T1mar-1 Ömer bin Cafer & 6000 \\
\hline Timar-1 Hasan bin Mehmed & 6000 \\
\hline Timar-1 Mehmed bin Abdullah & 6000 \\
\hline Timar-1 Hasan bin Mustafa & 6000 \\
\hline T1mar-1 Süleyman & 6000 \\
\hline Timar-1 Ebubekir bin Kasım & 6000 \\
\hline Tımar-1 Karagöz Hasan & 6000 \\
\hline Timar-1 Behram Abdullah & 6000 \\
\hline Timar-1 Ali bin Mustafa & 6000 \\
\hline Tımar-1 Seyyid Ahmed & 6000 \\
\hline
\end{tabular}




\begin{tabular}{|c|c|}
\hline Tımar-1 Salih bin Yusuf & 6000 \\
\hline Timar-1 Mehmed Bin Mustafa & 6000 \\
\hline Timar-1 Abdullah & 6000 \\
\hline Timar-1 Üveys & 6000 \\
\hline Tımar-1 Ali bin Mehmed & 6000 \\
\hline Tımar-1 Ramazan --? Hasan Beğ & 6000 \\
\hline Tımar-1 Mustafa Divane & 6000 \\
\hline Timar-1 Mustafa bin Hasan & 6000 \\
\hline T1mar-1 İnebey & 6000 \\
\hline Timar-1 Ali bin Osman (ber vech-i tekmil) & 5999 \\
\hline Timar-1 Mustafa bin Mehmed & 5999 \\
\hline Tımar-1 Hüseyin bin Yusuf (ber vech-i tekmil) & 5999 \\
\hline Tımar-1 Hüseyin bin Veli & 5999 \\
\hline Tımar-1 Ali Kasım & 5999 \\
\hline Tımar-1 Ömer bin Ali & 5999 \\
\hline Timar-1 Pervane bin Mehmed & 5999 \\
\hline Timar-1 Mustafa bin Mehmed & 5999 \\
\hline Timar-1 Mehmed bin Divane Hasan & 5999 \\
\hline Timar-1 Yusuf Divane & 5999 \\
\hline Tımar-1 --? & 5000 \\
\hline T1mar-1 Mustafa bin Ali & 4000 \\
\hline Timar-1 Mehmed bin Pervane & 3500 \\
\hline Tımar-1 Hasan bin Halil & 3344 \\
\hline Timar-1 Mustafa bin Sinan (ber vech-i tekmil) & 5999 \\
\hline Tımar-1 Hüseyin bin Yusuf & 2000 \\
\hline T1mar-1 İlyas & 3000 \\
\hline Tımar-1 Ali bin İbrahim (ber vech-i tekmil) & 6000 \\
\hline Toplam & 1.077 .440 \\
\hline
\end{tabular}

Tablo 4'ü yorumlayacak olursak İstolni Belgrad Sancağı tımar icmal defterine 1570 yılında toplam 1.077.440 akçe tutarında 141 adet sipahi tımarının kaydedildiği anlaşılmaktadır. Bu tımarlardan 14 adeti ber vech-i tekmîl usulüne göre dağıtılmıştır. ${ }^{5}$ Kaydedilen 141 adet sipahi tımarı içerisinde en yüksek meblağa sahip olanı 18.500 akçe ile Tur Ali bin Hasan'a ait iken en düşük meblağa sahip tımar ise 2000 akçe ile Hüseyin bin Yusuf’a aittir. Genel anlamda bakıldığında incelediğimiz defterde sipahi tımarlarının

\footnotetext{
${ }^{5}$ Ber vech-i tekmîl tımar tevcih usulü hakkında detaylı bilgi için bkz. İnalcık, "a.g.m.”, s.759.
} 
meblağlarına göre en yüksekten en düşüğe doğru sıralanarak kaydedildiği dikkat çekmektedir. 1570 yılında İstolni Belgrad Sancağı'nda toplam 141 adet tımarın sadece 15 adeti 10.000 akçe ve üzeri bir meblağa sahipken geri kalanların çoğunluğu 6000 ila 8500 akçe arasında yoğunlaşmaktadır. Defterdeki verilere göre; İstolni Belgrad Sancağı'nda tımar tahsis edilen kimseler arasında sipahilerden başka İstolni Belgrad Livası Seraskeri Mümin Ağa, Dergah-1 Ali Yeniçerilerinden Süleyman bin Davud, Budin Çavuşlarından Nasuh Ağa, Budin Defter Çavuşlarından Recep Ağa...vb. kişilerin bulunduğu görülmektedir. Defterdeki veriler arasında dikkat çeken bir diğer husus ise Budin Yeniçerilerinden Mehmed Çavuş'un biraderi Osman Bey'e de 6500 akçe tutarında tımar tahsis edilmiş olmasıdır. Genel anlamda buradaki sipahi tımarlarına bakıldığında kendilerine tımar tahsis edilenler arasında kılıç tımarı ya da başlangıç tımarı alan kişi sayısının 4 olduğu geri kalanların ise daha kıdemli sipahiler olduğu varsayilabilir.

İstolni Belgrad Sancağı'ndaki erbab-1 tımarları has, zeamet ve tımar olarak ayrı ayrı tablolarda verip analiz ettikten sonra 1570 yılında sancak dahilindeki gelirlerin ve dirliklerin genel durumu aşağıda Tablo 5 'te verilmiştir.

Tablo 5: 1570 Yılında İstolni Belgrad Sancağı'ndaki Dirliklere Toplu Bakış

\begin{tabular}{|l|l|c|c|}
\hline \multicolumn{2}{|l|}{ İstolni Belgrad Sancă̆ı'ndaki Dirlikler } & Miktarı & \% \\
\hline \multirow{2}{*}{ Havâss-1 } & Hümâyûn & 402.000 & 21,7 \\
\cline { 2 - 4 } & Vüzerâ & 294.518 & 15,9 \\
\hline Zeamet & 84.050 & 4,5 \\
\hline Timar & 1.077 .440 & 57,9 \\
\hline Toplam & $\mathbf{1 . 8 5 8 . 0 0 8}$ \\
\hline
\end{tabular}

497 numaralı Tımar İcmal deftere göre; 1570 yılında İstolni Belgrad Sancağı dahilindeki gelirlerin toplamı 1.858.008 akçedir. Bu meblağın 402.000 akçesi padişah hassı olarak 294.518 akçesi ise vüzerâ hasları olarak kaydedilmiştir. Bu açıdan bakıldığında İstolni Belgrad Sancağı'nda 696.518 akçe olarak tahsis edilen hasların toplamı sancak gelirlerinin de \%37,6'sını oluşturmaktadır. Haslardan sonra 84.050 akçe olarak kaydedilen zeametler ise sancak gelirlerinin \% 4,5 gibi çok küçük bir meblağını oluşturmaktadır. Hiyerarşinin en alt basamağında yer alan tımar gedikleri ise toplam 1.077 .440 akçe ile sancak gelirlerinin \%57,9'una tekabül etmektedir. Bu verilere göre 1570 yılında İstolni Belgrad Sancağ gelirlerinin yarısından fazlasının sipahi tımarı olarak tahsis edildiği anlaşılmaktadır.

Sonuç olarak defterdeki verilerden esasen merkezden çok uzak ve Habsburg sınırında yer almasına rağmen İstolni Belgrad Sancağı'nda da Osmanlı tımar sisteminin başarıyla uygulandığını, sistemdeki unsurların has, zeamet ve tımarların tamamının bulunduğunu elde etmekteyiz. Bilindiği üzere Tımar Sistemi genellikle merkezi otorite gücünün yoğun bir şekilde hissedildiği dolayısıyla merkeze kısmen yakın bölgelerde daha kolay uygulanmaktaydı. Merkezden uzak ve yerel güçlü unsurların yoğun olduğu bölgelerde ise genellikle ya vassallık sistemi ya da yıllık salyâne ödemek şartıyla Osmanlı hakimiyeti tesis edilirdi. Araştırmamızda tespit ettiğimiz gibi İstolni Belgrad Sancağı'nda XVI.yüzyılın son çeyreği gibi gerek ekonomik zorlukların, gerekse Uzun İran ve Avusturya Savaşlarının arefesinde bölgede doğrudan Osmanlı hakimiyetinin uygulandığı, sınır bölgesi olmasına rağmen yerel gayrimüslim unsurlar yerine Müslimlere dirlikler tevcih edildiği anlaşılmaktadır. Buradan da Macaristan'da Mohaç Savaşı sonrasında kısa bir dönem (15261541) vassallık sistemi uygulanmasına rağmen ilerleyen süreçte Osmanlı Devleti’nin tahrir ve 
tımar Sistemi vasıtasıyla toprakları dirlikler halinde sipahilere dağıtarak doğrudan hakimiyetini kurduğunu ifade edebiliriz. Ayrıca burada da tımar sistemi içerisindeki dirliklerin mali sınırları 20.000 akçeye kadar olan gelirlerin tımar, 100.000 akçeye kadar olanların zeamet ve 100.000 akçe ve üzerindekilerin ise has olarak kaydedilme kuralının istisnasız bir şekilde uygulandığını ifade edebiliriz. Son söz olarak incelediğimiz defterdeki verilere göre; İstolni Belgrad Sancağı'nda 1570 yılında erbab-1 tımarın tamamının Müslümanlardan oluştuğu anlaşılmaktadır.

\section{Kaynakça}

\section{A.Arşiv Belgeleri}

Devlet Arşivleri Başkanlı̆̆ı Osmanlı Arşivi, TT.0497.

\section{B. Tetkik Eserler}

Acun, F. (2002), “Klasik Dönem Eyalet İdare Tarzı Olarak Timar Sistemi ve Uygulaması”, Türkler, 9, ss.899-908.

Akdağ, M. (1945), “Timar Rejiminin Bozuluşu”, Ankara Üniversitesi DTCF Dergisi, 3, (4), ss.419-431.

Barkan, Ö. L. (1977), “Timar”, $\dot{I} A$,12/1, ss.286-333.

Bilge, S.M. (2001), “Macaristan'da Osmanlı Hakimiyetinin ve İdarî Teşkilatının Kuruluşu ve Gelişmesi”, OTAM (Ankara Üniversitesi Osmanlı Tarihi Araştırma ve Uygulama Merkezi Dergisi), 11, ss.33-81.

Dávid, G. (2001), “İstolni Belgrad”, D.İ.A., 23, ss.405-407.

Erdoğan Özünlü, E. (2010), "Osmanlı Ordusunda Bir Motivasyon ve Terfi Kaynağı:

“Terakki” Tevcihi”, Uluslararası Sosyal Araştırmalar Dergisi, 3/11,ss.238-244.

Evliya Çelebi,(2011), Evliya Çelebi Seyahatnâmesi, haz.Mümin Çevik, VI, Üçdal Neşriyat, İstanbul.

Fekete, L. (1949), “Osmanlı Türkleri ve Macarlar 1366-1699”, Belleten, XIII, 52, ss.663-743.

(1961), “Macaristan'da Türklerin Mülk Sistemi”, çev. M.Tayyib Gökbilgin, İstanbul Üniversitesi Tarih Dergisi,16, ss.25-42.

Fügedi, E. (1969), "Der Stadtplan von Stuhlweissenburg und die Anfänge des Bürgertums in Ungarn”, Acta Historica Academiae Scientiarum Hungaricae, 15,(1/2), ss.103-136.

Gökbilgin, M.T. (1997), “Süleyman I”, M.E.B. İslam Ansiklopedisi, XI, ss.99-155.

Györfyy, G. (1971), "Dem Gedächtnis Stephans, des ersten Königs von Ungarn”, Acta Historica Academiae Scientiarum Hungaricae, 17,(1/2), pp.1-11.

İnalcık, H. (1964), “Osmanlı Timar Rejimi ve Sipahi Ordusu”, Türk Kültürü, 25-36, 3, ss.758765.

(2000), Osmanlı Imparatorluğu'nun Ekonomik ve Sosyal Tarihi, Cilt I,ed. Halil İnalcık ve Donald Quataert, çev. Halil Berktay, Eren Yayıncılık.

(2009), Devlet-i 'Aliyye-Osmanlı İmparatorluğu Üzerine Araştırmalar-I, Türkiye

İş Bankası Yayınları, İstanbul.

(2012),“Timar”, D.I.A., 41, s.168-173.

İpçioğlu, M. (1990), “Kanunî Süleyman'ın Estergon (Esztergom) Seferi 1543-Yeni Bir Kaynak" Osmanlı Araştırmaları, 10, ss.137-159. 
Kaldy-Nagy, G. (1972), "Macht und Immobiliarvermögen eines türkischen Beglerbegs im 16. Jahrhundert",Acta Orientalia Academiae Scientiarum Hungaricae,25, LVDOVICO LIGETISEPTVAGENARIO HOC VOLVMEN DAMVS DICAMVS DEDICAMVS, pp.441-450.

(1974-a), "Suleimans Angriff auf Europa", Acta Orientalia Academiae Scientiarum Hungaricae, 28, pp.163-212.

(1974-b), “Tımar Sisteminin Macaristan'da Tarımsal Üretime Etkisi”, çev. Şadan Karadeniz, Belleten, 38, 151, ss.499-508.

(1996), "XVI.Yüzyılda Osmanlı İmparatorluğunda Merkezi Yönetimin Başlıca Sorunları”, Tarih Araştırmaları Dergisi, VII, 12-13, ss.49-55.

Kopcăn, V. (1973), "XVI-XVII. Asırlarda Kuzey Macaristan Hudut Boylarında Osmanlı Hakimiyetinin Karakteri”, VII.Türk Tarih Kongresi, C.II, ss.618-625.

Kubinyi, A. (1991), "Buda-Die Mittelalterliche Hauptstadt”, Budapest Im Mittelalter, Braunschweig, ss.15-41.

Öztürk, Y. (2013), “Timar-Thema Teriminin Ortaya Çıkması Bizans Uygulaması ve Osmanlı İle Mukayesesi”, Osmanlı Tarihi Araştırma ve Uygulama Merkezi Dergisi (OTAM), 31, ss.157-208.

Peçevi İbrahim Efendi, (1981), Peçevi Tarihi I, haz. Bekir Sıtkı Baysal, Kültür Bakanlığı Yayınları, Ankara.

Schaendlinger, A.C. (1984), "Die Osmanisch-Habsburgische Diplomatie İn Der Ersten Halfte Des 16.JHTDS”, Osmanlı Araştırmaları, IV, ss.181-196.

Turan, N.S. (2005), “Kanuni’nin Macaristan Siyaseti- Macaristan'da Osmanlı Kültüründen İzler", Toplumsal Tarih,138, ss.46-53.

Uzunçarşılı, İ.H. (1998), Osmanlı Tarihi, C.II, Ankara.

Yücel, Y. (1991), Muhteşem Türk Kanuni İle 46 Yll, Türk Tarih Kurumu Yayınları, Ankara. 